\title{
Synthesis of Alkali-Activated Binary Blended Silico-Manganese Fume and Ground Blast Furnace Slag Mortar
}

\author{
Muhammad Nasir ${ }^{1}$, Megat Azmi Megat Johari ${ }^{2}$, Moruf Olalekan Yusuf ${ }^{3 *}$, Mohammed Maslehuddin ${ }^{4}$ \\ and Mamdouh A. Al-Harthi ${ }^{5,6}$
}

\begin{abstract}
This study was aimed at developing novel and sustainable alkali-activated binder of silico-manganese fume (SMF) and ground blast furnace slag (BFS) at room temperature. The level of BFS substitution was varied from $0-50 \%$ and activation was done using $10 \mathrm{M} \mathrm{NaOH}$ and $\mathrm{Na}_{2} \mathrm{SiO}_{3}$ of an initial silica modulus of 3.3. The $\mathrm{Na}_{2} \mathrm{SiO}_{3} / 10 \mathrm{MNaOH}$ ratio was kept constant at 2.5. The setting time, flow and compressive strength were evaluated and complemented with the microstructural and bond characteristics of the product. A 28-day strength of $45 \mathrm{MPa}$ was achieved with the base materials ratio $(\mathrm{BFS} /(\mathrm{BFS}+\mathrm{SMF})$ ) of 0.3 . The activation of SMF resulted in the formation of glaucochroite and nchwaningite minerals $(\mathrm{C}-\mathrm{Mn}-\mathrm{S}-\mathrm{H})$ while the inclusion of BFS influenced the formation of potassium feldspar (K-A-S-H), gehlenite hydrate $(\mathrm{C}-\mathrm{A}-\mathrm{S}-\mathrm{H})$ and additional $\mathrm{C}-\mathrm{S}-\mathrm{H}$ due to later-age contribution of hydration of BFS. The Manganese in SMF contributed significantly to the consistency of the mixture while lime in BFS improved the microstructure thereby enhancing strength of the developed alkali-activated binder.
\end{abstract}

\section{Introduction}

The alkali-activation technology is gaining importance owing to its economic and ecological advantages that result in a reduction in the consumption of ordinary Portland cement (OPC) and hence a decrease in the greenhouse gas $\left(\mathrm{CO}_{2}\right)$ emission. The production of an alkali-activated binder $(\mathrm{AAB})$ requires alkaline activation of aluminosilicate or calcium-aluminate based source material, such as fly ash, blast furnace slag or other wastes. An alkaline activator could be of low to high concentration alkalis or silicate of alkaline metal elements, such as sodium or potassium (Provis 2014). The resulting binder possesses excellent strength and durability together with the capability of immobilizing the toxic metals (Salami et al. 2017; Vu and Gowripalan 2018). The use of a combination of $\mathrm{Na}_{2} \mathrm{SiO}_{3}$ and $\mathrm{NaOH}$ promotes the activation of an AAB (Phoo-Ngernkham et

${ }^{1} \mathrm{Ph} . D$. Researcher, School of Civil Engineering, Universiti Sains Malaysia, Pulau Pinang, Malaysia.

${ }^{2}$ Professor, School of Civil Engineering, Universiti Sains Malaysia, Pulau Pinang, Malaysia.

${ }^{3}$ Assistant Professor, Department of Civil and Environmental Engineering, University of Hafr Al Batin, Hafr Al Batin 31991, Saudi Arabia.

*Corresponding author, E-mail: moruf@uhb.edu.sa

${ }^{4}$ Senior Researcher (Professor), Center for Engineering Research, Research Institute, King Fahd University of Petroleum and Minerals.

${ }^{5}$ Professor, Department of Chemical Engineering, King Fahd University of Petroleum and Minerals.

${ }^{6}$ Professor, Center of Research Excellence in Nanotechnology, King Fahd University of Petroleum and Minerals. al. 2015, 2016). The molarity or concentration of $\mathrm{NaOH}$ that enhances the dissolution of base materials with high silica content is reported to be within the range of 8 12M (Yusuf et al. 2014a; Heah et al. 2013; Nagaraj and Babu 2018) while the optimum activator ratio $\left(\mathrm{Na}_{2} \mathrm{SiO}_{3} / \mathrm{NaOH}\right)$ varies from $2-3$ (Ibrahim et al. 2019, 2017; Mohseni 2018).

The proliferation of silico-manganese fume (SMF) calls for its usage in large quantities. For instance, as per 2012 statistics of International Manganese Institute (IMnI), the world annual production of SM waste was 14.8 MMT. In the light of this, there is a need for utilizing this waste material (SMF) together with others with hydraulic property, such as blast furnace slag (BFS). It is hypothesized that these two materials may complement each other through alkali activation to provide a binder with good structural characteristics. The development of a binder with good properties will lead to the use of SMF in large quantities along with BFS whose hydraulic characteristic has been established (Puertas et al. 2000). Other researchers also established the contribution of BFS to the mechanical and microstructural characteristics of AAB developed with other precursors, such as fly ash, palm oil fuel ash, metakaolin and others (Rashad 2013; Yusuf et al. 2014b; Bernal et al. 2011). The higher quantity of $\mathrm{Ca}^{2+}$ in BFS could play a charge balancing role, contribute to carbonation effect or prompt primary or secondary hydration reaction when it reacts with silica to form calcium silicate hydrate (C-SH) (Haha et al. 2011; Fernández-Jiménez et al. 2003; Zhang et al. 2008; Liu et al. 2018; Bonk et al. 2003).

Prior studies on silico-manganese slag (SMS) conducted by Kumar et al. (2013) already established mechanical treatment of the raw materials through ball milling processes (attritions and eccentric vibration). 
Table 1 Mix design parameters.

\begin{tabular}{|c|c|c|c|c|c|c|c|c|c|}
\hline \multirow{2}{*}{ Mix ID } & \multicolumn{4}{|c|}{ Ingredient quantities $\left(\mathrm{kg} / \mathrm{m}^{3}\right)$} & \multicolumn{5}{|c|}{ Constant ratios } \\
\hline & SMF & BFS & FA & FW & $\mathrm{SH}$ & SS & FA/PMs & $\mathrm{SS} / \mathrm{SH}$ & AAs/PMs \\
\hline $\mathrm{AASB}_{0}$ & 723.0 & - & 1301.4 & 14.46 & 103.2 & 258 & 1.8 & 2.5 & 0.5 \\
\hline $\mathrm{AASB}_{0.1}$ & 650.7 & 72.3 & 1301.4 & 14.46 & 103.2 & 258 & 1.8 & 2.5 & 0.5 \\
\hline $\mathrm{AASB}_{0.2}$ & 578.4 & 144.6 & 1301.4 & 14.46 & 103.2 & 258 & 1.8 & 2.5 & 0.5 \\
\hline $\mathrm{AASB}_{0.3}$ & 506.1 & 216.9 & 1301.4 & 14.46 & 103.2 & 258 & 1.8 & 2.5 & 0.5 \\
\hline $\mathrm{AASB}_{0.4}$ & 433.8 & 289.2 & 1301.4 & 14.46 & 103.2 & 258 & 1.8 & 2.5 & 0.5 \\
\hline $\mathrm{AASB}_{0.5}$ & 361.5 & 361.5 & 1301.4 & 14.46 & 103.2 & 258 & 1.8 & 2.5 & 0.5 \\
\hline
\end{tabular}

This treatment is capable of reducing the setting time of an activated SMS. Nath and Kumar (2016) also reported that a part replacement of BFS with SMS in BFS/OPC paste could delay both initial and final setting of the binder. The inhibition in the setting was attributed to the presence of $\mathrm{MnO}$ in SMS (Frias and Rodríguez 2008; Frias et al. 2005; Péra et al. 1999). However, there is a distinctive difference between SMS and SMF by virtue of their oxide composition owing to the dearth of $\mathrm{K}_{2} \mathrm{O}$ and $\mathrm{MnO}_{2}$, and higher $\mathrm{CaO}$ and $\mathrm{Al}_{2} \mathrm{O}_{3}$ in the former than the latter, respectively (Frias and Rodríguez 2008).

The quantity of potassium in SMF could be higher than $15 \%$ due to the presence of potassium aluminosilicate $\left(\mathrm{KAlSi}_{3} \mathrm{O}_{8}\right)$ (Najamuddin et al. 2019) or other impurities, such as potassium feldspar generally occurring in manganese oxide ore (Zhong et al. 2017). Abdulkareem et al. (2018) reported that high $\mathrm{K}_{2} \mathrm{O}$ content could contribute to the strength in the presence of silica and lime in the OPC-based binder. However, the role of $\mathrm{K}_{2} \mathrm{O}$ in $\mathrm{AAB}$ synthesis co-existed with $\mathrm{MnO}$ in $\mathrm{SMF}$ and their synergy with BFS, is not yet fully elucidated.

Hitherto, SMF and BFS have not been used towards developing $\mathrm{AAB}$ at room temperature. Similarly, the role of Mn-bearing particles on the fresh and strength properties of $\mathrm{AAB}$ with these two materials is not yet fully understood. The reported study was aimed at developing a sustainable AAB by utilizing high volume of SMF in combination with BFS. The findings are expected to promote the use of both industrial byproducts in the development of a green binder.

\section{Materials and methods}

\subsection{Materials and sample preparation}

\section{(1) Precursor materials}

Silico-manganese fume (SMF) was collected from a ferro-alloy manufacturing industry at Jubail, Saudi Arabia. For every ton of ferro-alloy production, about $10 \%$ of SMF waste is generated. As received SMF was then collected and sieved through 40 micron sieve to eliminate any lumps. Ground blast furnace slag (BFS) was procured from a local ready-mix concrete plant.

The particle size distribution of the precursor materials (PMs) was determined using Malvern's Mastersizer 2000 with a measuring range of 0.02 to 2000 microns. A gas pycnometer, AccuPyc II 1340, was used to determine the specific gravity and the bulk density of the PMs. An automatic gas sorption data acquisition and reduction machine, Quantachrome ASiQwin, was used to determine the surface area of the PMs. X-ray fluorescence (XRF) spectrometer, PANalytic model EPSILON $3 \mathrm{XL}$, was used to determine the elemental composition of the PMs.

\section{(2) Synthesis of alkaline activators}

The alkaline activators (AAs) consisted of sodium hydroxide $(\mathrm{NaOH})$ and sodium silicate $\left(\mathrm{Na}_{2} \mathrm{SiO}_{3}\right)$ while their combinations with the addition of free water (FW) is referred to as combined alkaline activators (CAAs). One liter of $10 \mathrm{M} \mathrm{NaOH}(\mathrm{SH})$ solution was prepared by mixing approximately $400 \mathrm{~g}$ of SH pellet (98.6\% purity) with distilled water and then allowed to cool for one day prior to its use. The composition of $\mathrm{Na}_{2} \mathrm{SiO}_{3}$ (SS) was as follows: $\mathrm{H}_{2} \mathrm{O}=62.50 \%, \mathrm{SiO}_{2}=28.75 \%$ and $\mathrm{Na}_{2} \mathrm{O}=$ $8.75 \%$ such that its initial silica modulus $(\mathrm{Ms}=$ $\mathrm{SiO}_{2} / \mathrm{Na}_{2} \mathrm{O}$ ) was 3.3 .

\section{(3) Specimen preparation}

Alkaline activated mortar (50 mm cube) and paste (25 $\mathrm{mm}$ cube) specimens were prepared by casting six mixes by varying the ratio of $\mathrm{BFS} /(\mathrm{SMF}+\mathrm{BFS})$ as 0 , $0.1,0.2,0.3,0.4$ and 0.5 . The mixtures were designated as $\mathrm{AASB}_{\mathrm{x}}$. For example, $\mathrm{AASB}_{0.3}$ means the AAB comprises $30 \%$ and $70 \%$ of BFS and SMF, respectively. The proportion of materials in the AASB mortar, as shown in Table 1, was selected based on the trial mixtures.

\section{(4) Mixing, placing and curing}

The mixture constituents was mixed in a Hobart bench top planetary mixer. The PMs were first mixed to remove the air-pocket followed by the addition of CAAs. The prepared AAB was placed in the molds in two layers by consolidating each layer for a duration of $12 \mathrm{~s}$. The surface of the specimens was levelled using a trowel and wrapped with plastic sheets to prevent moisture loss before being placed at ambient laboratory temperature $\left(25 \pm 2^{\circ} \mathrm{C}\right)$ for setting purpose. The specimens were demoulded after $24 \mathrm{~h}$, and then placed in polythene bags for continuous curing till the age of testing.

\subsection{Evaluation}

\section{(1) Setting time}

The initial and final setting time of AASB paste were measured according to ASTM C 191 using a Vicat apparatus. The initial setting time was measured after every $5-10 \mathrm{~min}$ interval until a penetration of $25 \mathrm{~mm}$ or less 
is achieved while the final setting time was recorded at every 3 - 5 min until the circular needle left no indentation or impression on the surface of the specimen.

\section{(2) Flow}

The flow of the developed $\mathrm{AAB}$ was evaluated as per ASTM C1437 and ASTM C230. This flow was measured after 10 and 20 min intervals in order to evaluate the flow retention. The resulting values were classified based on the diameter of spread as either fluid $(>200$ $\mathrm{mm})$, plastic $(140-200 \mathrm{~mm})$ or dry $(<140 \mathrm{~mm})$, as per BS EN 1015.

\section{(3) Compressive strength}

Compressive strength was determined on $50 \mathrm{~mm}$ cube specimens, according to ASTM C109. Mortar specimens were retrieved from plastic bags after 3, 7 and 28 days and compressive load was applied using a compression testing machine, model ELE-ADR-Auto, at a loading rate of $0.9 \mathrm{kN} / \mathrm{s}$. Three specimens were tested from each batch at each age and their average readings were reported.

\section{(4) Microstructure and composition}

In order to study the contribution of SMF and BFS on the hydration products, $\mathrm{AASB}_{0}$ (BFS-free) paste specimens were compared with the specimens exhibiting optimum strength $\left(\mathrm{AASB}_{0.3}\right)$ after 7 -day curing. The selected specimens were ground and sieved through 100 $\mu \mathrm{m}$ sieve to be used in X-ray diffraction (XRD) and Fourier transform infrared (FTIR) spectroscopy. A Rigaku MiniFlex II - Benchtop X-ray diffractometer was utilized to obtain mineralogy of the products. The X-ray analysis parameters were $\mathrm{Cu}-\mathrm{K} \alpha \mathrm{l}$ as the radiation source with the relevant voltage $(30 \mathrm{kV})$ and current $(15$ $\mathrm{mA}$ ) while the scan speed was $2.5 \mathrm{deg} . / \mathrm{min}$. Thermo Fisher Scientific Nicolet FT-IR Spectrometer was used to detect the functional groups or bond characteristics. The IR spectra were generated between the wavenumbers $400-4000 \mathrm{~cm}^{-1}$. The morphology and elemental composition of the specimens were evaluated using JEOL model JSM-6610-LV scanning electron microscope (SEM) equipped with an energy dispersive spectrophotometer (EDS). The SEM-EDS analysis was performed on fragmented cube specimens, coated with gold and affixed on a brass holder using a double-sided cop-

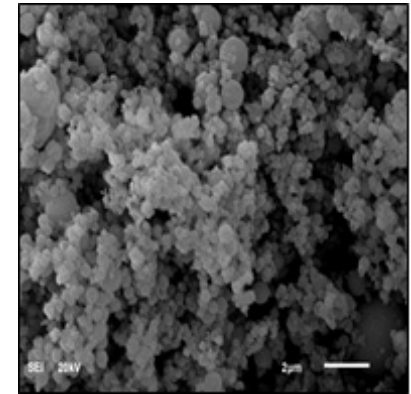

(a)

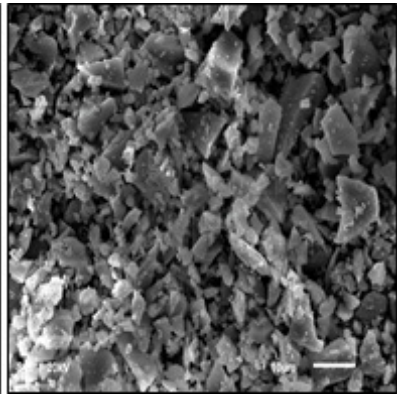

(b)
Fig. 1 Morphology of: (a) SMF and (b) BFS.
Table 2 Physical properties of SMF and BFS.

\begin{tabular}{|c|c|c|c|c|c|c|}
\hline \multirow{2}{*}{ PMs } & $\begin{array}{c}\text { Density } \\
\left(\mathrm{g} / \mathrm{cm}^{3}\right)\end{array}$ & $\mathrm{d}_{10}$ & $\mathrm{~d}_{50}$ & $\mathrm{~d}_{90}$ & $\begin{array}{c}\text { Span } \\
\left(\mathrm{d}_{90}-\mathrm{d}_{10}\right) / \mathrm{d}_{50}\end{array}$ & $\begin{array}{c}\text { Specific } \\
\text { surface } \\
\text { area } \\
\left(\mathrm{m}^{2} / \mathrm{g}\right)\end{array}$ \\
\hline SMF & 2.876 & 0.588 & 29.173 & 179.958 & 6.15 & 10.1 \\
\hline BFS & 2.933 & 1.541 & 13.585 & 39.211 & 2.78 & 2.5 \\
\hline
\end{tabular}

per tape, under the current supply of $20 \mathrm{~mA}$.

\section{Results and discussion}

\subsection{Physical, chemical and mineralogical char- acteristics of raw PMs}

The BFS particles were irregular to polygonal in shape while the SMF particles were round and spherical (Fig. 1). The specific surface area of SMF and BFS was 10.1 and $2.5 \mathrm{~m}^{2} / \mathrm{g}$, respectively. Generally, BFS has relatively smaller particles as shown by the proportions of particle sizes corresponding to $\mathrm{d}_{10}, \mathrm{~d}_{50}$, and $\mathrm{d}_{90}$ (Table 2) while its size is more uniform as shown in the span $\left(\left(\mathrm{d}_{90^{-}}\right.\right.$ $\left.\mathrm{d}_{10}\right) / \mathrm{d}_{50}$ ) value in comparison with SMF particles which also has a bigger surface area. The d-values represent the particle size distribution of a material, such that $d_{10}$, $\mathrm{d}_{50}$ and $\mathrm{d}_{90}$ indicate the particle size relevant to 10,50 and $90 \%$ of cumulative mass, respectively. The disparity in the grain morphology, surface area and particle size distribution of SMF and BFS indicate that these materials could contribute to the rate of reaction in synergy while the difference in the texture could also influence the workability through particle interlocking, and frictional or lubricating effects. These attributes are expected to significantly affect the rheology of the developed binder. Further, BFS is denser than SMF, as shown in Table 2. This could significantly affect the density of the developed AAB. Figure 2 shows the particle size distribution curves of both precursors.

The major oxides in SMF include $\mathrm{Mn}, \mathrm{Si}$, and $\mathrm{K}$ which constitute more than $70 \%$ of the total material oxide composition. The minor oxides, such as $\mathrm{Ca}$ and $\mathrm{Mg}$ constituted about $13 \%$. In contrast, $90 \%$ of BFS is composed of oxides of $\mathrm{Ca}, \mathrm{Si}$ and $\mathrm{Al}$ (Table 3). It is important to note that the quantity of $\mathrm{K}_{2} \mathrm{O}$ in SMF is very high, whereas it is insignificant in the BFS. A reverse trend is noted in the quantity of $\mathrm{Al}_{2} \mathrm{O}_{3}$. Therefore, there is propensity that $\mathrm{K}_{2} \mathrm{O}$ and $\mathrm{Al}_{2} \mathrm{O}_{3}$ together with

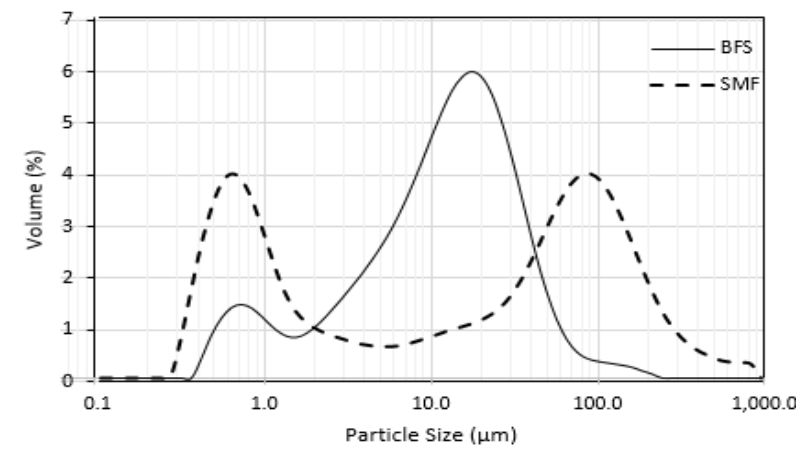

Fig. 2 Particle size distribution of PMs. 
Table 3 Oxide composition of SMF and BFS.

\begin{tabular}{|c|c|c|c|c|c|c|c|c|c|c|c|c|c|c|c|}
\hline \multirow[b]{2}{*}{ PMs } & \multicolumn{14}{|c|}{ Oxide (\%) } & \multirow{2}{*}{ LOI (\%) } \\
\hline & $\mathrm{CaO}$ & $\mathrm{MnO}$ & $\mathrm{SiO}_{2}$ & $\mathrm{~K}_{2} \mathrm{O}$ & $\mathrm{Al}_{2} \mathrm{O}_{3}$ & $\mathrm{SO}_{3}$ & $\mathrm{MgO}$ & $\mathrm{Fe}_{2} \mathrm{O}_{3}$ & $\mathrm{Cl}$ & $\mathrm{ZnO}$ & $\mathrm{P}_{2} \mathrm{O}_{5}$ & $\mathrm{Ag}_{2} \mathrm{O}$ & $\mathrm{TiO}_{2}$ & Total & \\
\hline SMF & 7.24 & 35.42 & 19.50 & 16.62 & 1.46 & 6.24 & 5.71 & 3.35 & 2.73 & 0.74 & 0.37 & 0.15 & - & 99.53 & 5.82 \\
\hline BFS & 49.02 & 0.40 & 29.32 & 0.41 & 12.19 & 2.03 & 4.50 & 0.83 & - & - & 0.34 & 0.11 & 0.66 & 99.81 & 1.25 \\
\hline
\end{tabular}

$\mathrm{MnO}, \mathrm{CaO}$, and $\mathrm{SiO}_{2}$ in both materials could play a synergistic role in the setting and strength development of the $\mathrm{AASB}_{\mathrm{x}}$ binder.

As shown in Fig. 3, SMF is crystalline in nature and it mainly consisted of quartz $\left(1-\mathrm{SiO}_{2}\right)(\mathrm{PDF} \# 85-0796)$, glaucochroite (2-CaMnSiO $\left.{ }_{4}\right)(\mathrm{PDF} \# 14-376)$, sylvite (3$\mathrm{KCl}$ (PDF\#04-0587) and wollastonite (4-CaSiO$)$ (PDF\#72-2284). The amorphous nature of BFS is indicated by peaks gehlenite [5- $\left.\mathrm{Ca}_{2} \mathrm{Al}\left(\mathrm{AlSiO}_{7}\right)\right]$ ( $\mathrm{PDF} \# 89-$ 1489 ) and akermanite $\left[6-\mathrm{Ca}_{2} \mathrm{Mg}\left(\mathrm{Si}_{2} \mathrm{O}_{7}\right)\right]$ (PDF\#771149 ) within the range of $27-33^{\circ} 2 \theta$.

\subsection{Setting time}

As shown in Fig. 4, the inclusion of BFS in AASB binders decreases the initial and final setting times. This may be attributed to the higher specific gravity and polygonal shape of BFS thereby enhancing the precipita-

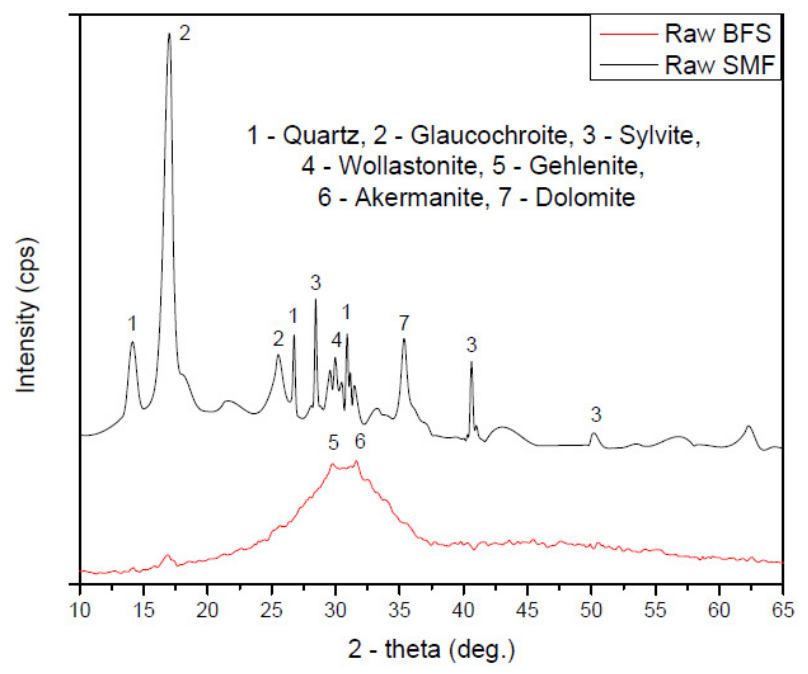

Fig. 3 X-ray diffractogram of PMs: SMF (top spectrum) and BFS (bottom spectrum).

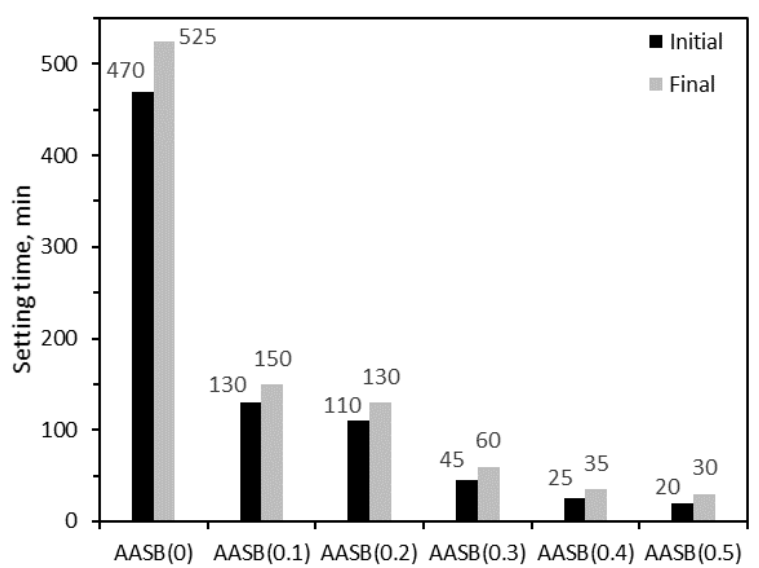

Fig. 4 Initial and final setting time of the AASB paste. tion of the oligomer within a short period of time in comparison with the BFS-free mixture $\left(\mathrm{AASB}_{0}\right)$. This is due to the formation of calcium aluminosilicate hydrate (CASH) that increases the density of the binder due to polycondensation process. The presence of $\mathrm{CaO}$ in the BFS increases the viscosity of the mixture (FernándezJiménez and Puertas 2001; Puertas et al. 2014) due to the formation of calcium carbonate upon reaction with atmospheric carbon dioxide, as shown in Eqn. 1.

$$
\mathrm{CaO}+\mathrm{CO}_{2} \rightarrow \mathrm{CaCO}_{3}
$$

BFS could also play a significant role of charge balancing in the condensation of aluminosilicate oligomers after initial dissolution by the alkaline activators thereby leading to the formation of additional C-S-H. It was noted that SMF alone takes a longer time of about 470 minutes for setting (initial) due to the paucity of $\mathrm{CaO}$. Consequently, the setting time decreases with an increase in the quantity of BFS, as shown in Fig. 4. Specifically, the initial and final setting time of AASB with $10 \%$ BFS $\left(\mathrm{AASB}_{0.1}\right)$ decreased by $72.3 \%$ and $71.4 \%$, respectively. This reduction increased to $76 \%$ and $75.23 \%$, respectively, as the quantity of BFS was increased to $20 \%$. Therefore, the extended setting recorded in the alkaline silico-manganese fume paste is attributed to the low $\mathrm{CaO} / \mathrm{SiO}_{2}$ ratio.

\subsection{Flow}

Figure 5 shows the flow of the developed AASB mortars. The flow generally decreases with BFS inclusion up to $50 \%$. The decrease in flow in the AASB with the incorporation of BFS may be attributed to the formation of C-S-H and the irregular shape of BFS having a nonlubricating effect on SMF particles due to an increase in the inter-particle frictional resistance. The excessive presence of $\mathrm{MnO}$ in the precursor materials is expected to influence the rheology of the binder. Therefore, the

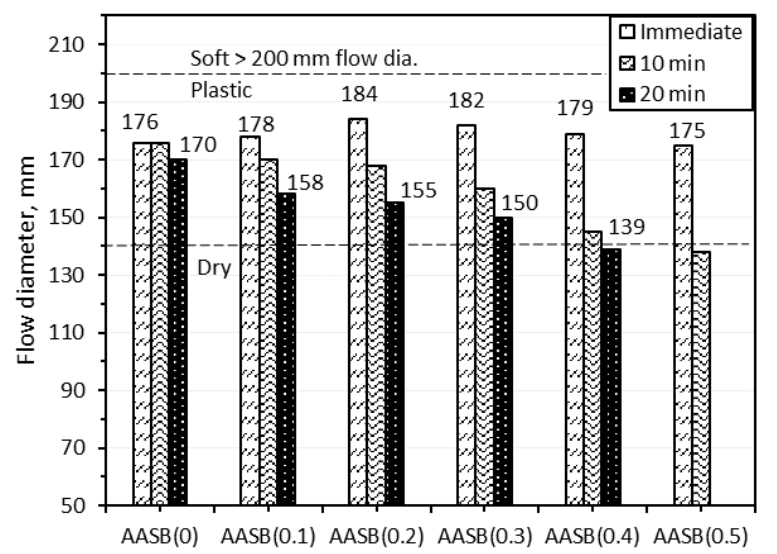

Fig. 5 Flow of the AASB mortar. 
rheology of the binder is controlled by $\mathrm{MnO} / \mathrm{CaO}$, as it appears that $\mathrm{MnO}$ in SMF dissolves faster in the alkaline activators than $\mathrm{CaO}$ contributed by BFS. An increase in the $\mathrm{MnO} / \mathrm{CaO}$ ratio increases the immediate flow from 176 to $184 \mathrm{~mm}$ up to $20 \%$ BFS addition $\left(\mathrm{AASB}_{0.2}\right)$, but any further addition of BFS decreases the flow from 184 to $175 \mathrm{~mm}$, as shown in Fig. 5. As the mixing continues, further $\mathrm{CaO}$ is formed from the complexes of BFS - depending on the concentration of the activators (Puertas et al. 2014) - thereby further decreasing the $\mathrm{MnO} / \mathrm{CaO}$ ratio. This causes decrease in flow of AASB mortar regardless of the level of BFS substitution, as indicated by the flow measurements taken after 10 and 20 mins of mixing (Fig. 5). Further, the mixture loses its consistency significantly as the BFS substitution level goes beyond $30 \%\left(\mathrm{AASB}_{0.3}\right)$.

\subsection{Compressive strength development}

Figure 6 shows the compressive strength development in $\mathrm{AASB}_{\mathrm{x}}$ mortars. The mortar specimens prepared with more than $30 \%$ BFS content were discarded due to dry consistency and quick setting which resulted in air voids and honeycombs in the specimen (Fig. 7). Generally, the strength of room-cured specimens increased with age. It is evident that the controlling factor governing the compressive strength is the ratio of $\mathrm{CaO} / \mathrm{SiO}_{2}$. This ratio increases as the level of substitution of BFS in the binary blending increases. Since BFS serves as a source of $\mathrm{CaO}$ supplement in the mixture, it is quite evident that the strength development follows the same pattern. The early strength increased by $122.2 \%$ due to the replace-

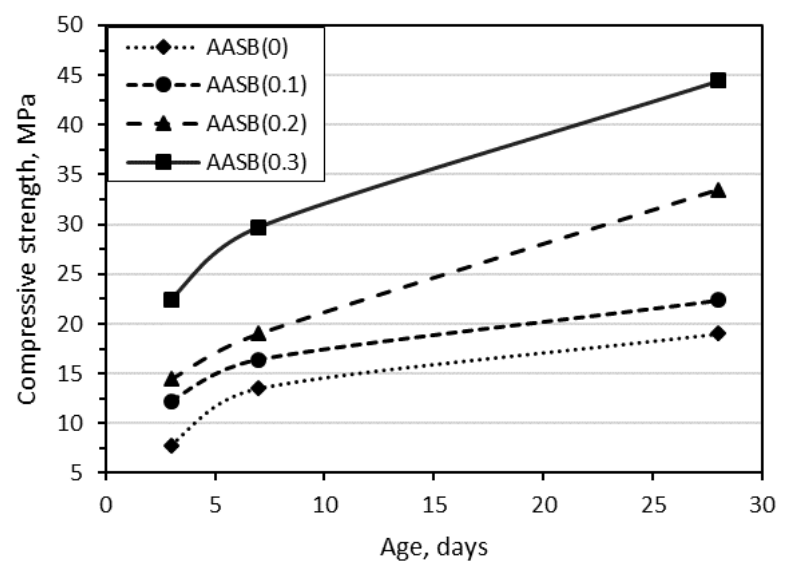

Fig. 6 Compressive strength development in AASB mortar. ment of $30 \%$ BFS while it was only $40.7 \%$ for $20 \%$ BFS, in comparison with the BFS-free specimens. However, there was a significant gain in strength after 28 days. This suggests that there could be a delayed hydration process leading to the formation of C-S-H (PDF\#722396, 40-0513, 11-0507), in parallel to the formation of condensed gehlenite $\left(\mathrm{Ca}_{2} \mathrm{Al}_{2} \mathrm{SiO}_{7}\right)(\mathrm{PDF} \# 89-1489)$ or stratlingite hydrate $\left[4-\mathrm{Ca}_{2} \mathrm{Al}_{2}\left(\mathrm{SiO}_{2}\right)(\mathrm{OH})_{10} .2 .5 \mathrm{H}_{2} \mathrm{O}\right]$ (PDF\#085-8414), nchwaningite $\left[1-\mathrm{Mn}_{2} \mathrm{SiO}_{3}(\mathrm{OH})_{2} \cdot \mathrm{H}_{2} \mathrm{O}\right]$ (PDF\#83-1006) and rancieite minerals [2-(Mn,Ca) $\mathrm{Mn}_{4}$ $\left.\mathrm{O}_{9} .3 \mathrm{H}_{2} \mathrm{O}\right]$ (PDF\#058-0466), as indicated by the X-ray peaks in Fig. 8. This dual product formation is more significant in the binders with $30 \%$ BFS. The 28-day compressive strength was $45,34,23$, and $19 \mathrm{MPa}$ in binders with $30,20,10$, and $0 \%$ BFS, respectively.

The morphology (Fig. 9) of $\mathrm{AASB}_{0}$ shows significant quantities of un-reacted/un-hydrated SMF particles due to lower $\mathrm{CaO} / \mathrm{SiO}_{2}$ with prolonged or interconnected cracks indicative of a weak and less dense microstructure. The weak microstructure of $\mathrm{AASB}_{0}$ suggests that there will be more ingress of atmospheric carbon dioxide to the binder resulting in the formation of $\mathrm{CaCO}_{3}$. This is evident by the presence of $\mathrm{C}$ and $\mathrm{O}$ peaks in the EDS profile.

A relatively dense microstructure is indicated by the $\mathrm{SEM}$ for specimen $\mathrm{AASB}_{0.3}$. Unlike specimen $\mathrm{AASB}_{0}$, the cracks are localized and disconnected. Further, there is fewer traces of unreacted SMF particles, this is also indicated by a decreased quantity of $\mathrm{Mn}$ in the EDS for this specimen. By comparing the EDS spectra (Table 4) of $\mathrm{AASB}_{0}$ and $\mathrm{AASB}_{0.3}$, it is evident that the denser mi-

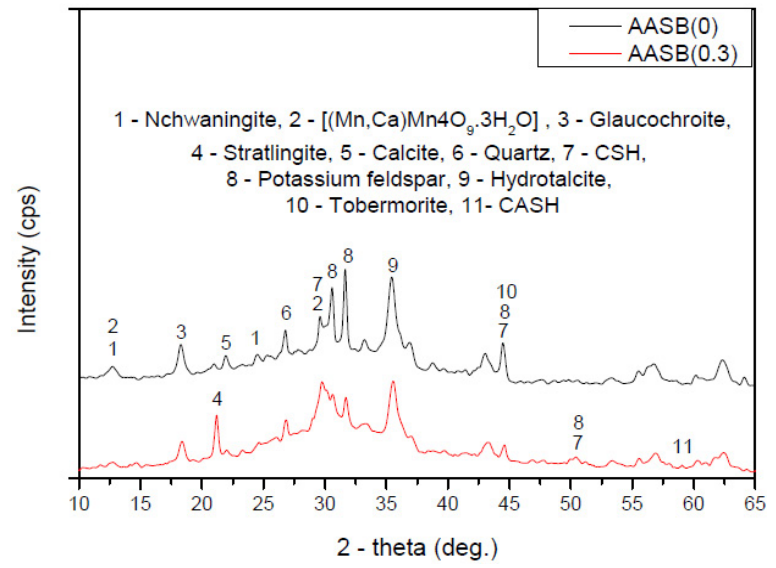

Fig. 8 X-ray diffractogram of $\mathrm{AASB}_{0}$ (top spectrum) and $\mathrm{AASB}_{0.3}$ (bottom spectrum).

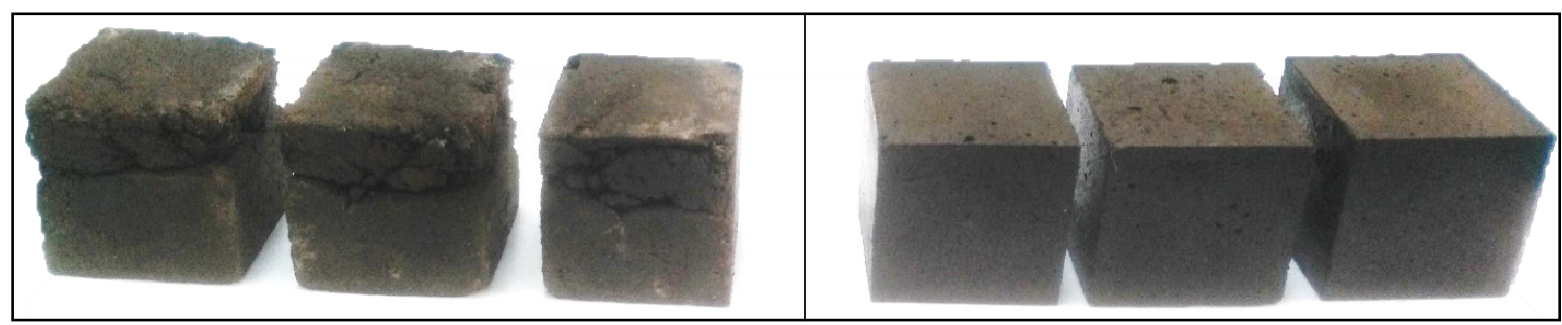

(a)

(b)

Fig. 7 Visual appearance of AASB specimens: (a) discarded (BFS $>30 \%$ ) (b) properly consolidated (BFS $=0-30 \%)$. 
crostructure of the latter (Fig. 9) has $\mathrm{Ca} / \mathrm{Si}$ ratio of 0.95 compared to 0.25 of the weaker microstructures of the former. More importantly, is the ratio of $\mathrm{Si} / \mathrm{Mn}$ which was 0.66 and 1.30 , respectively, while $\mathrm{Ca} / \mathrm{Mn}$ was also 0.16 and 1.23 , respectively. Therefore, for the synthesis of silico-manganese fume alkaline binder, the ratio of $\mathrm{Ca} / \mathrm{Si}, \mathrm{Si} / \mathrm{Mn}$ and $\mathrm{Ca} / \mathrm{Mn}$ ratios could be the relevant indicators to determine the performance of the binder in terms of the strength characteristics. This further strengthens the presence of C-Mn-H, C-S-H and C-A-S$\mathrm{H}$ phases in the $\mathrm{X}$-ray diffractograms of Fig. 8. The peak for potassium feldspar $\left(\mathrm{KAlSi}_{3} \mathrm{O}_{8}\right)\left(32\right.$ and $45^{\circ} 2 \theta$; PDF\#71-0897) is more pronounced in $\mathrm{AASB}_{0}$ for a $\mathrm{Ca} / \mathrm{K}$ ratio of 0.32 , and upon inclusion of $30 \%$ BFS the peak disappeared and appeared apparently at $\sim 50.4^{\circ} 2 \theta$ as the $\mathrm{Ca} / \mathrm{K}$ increased to 1.75 (Table 4 ) in the more stable and dense $\mathrm{AASB}_{0.3}$ binder. Thus, the presence of potassium oxide in SMF could only contribute to the strength development positively in the presence of $\mathrm{CaO}$ or $\mathrm{SiO}_{2}$ just as the $\mathrm{Si} / \mathrm{K}$ ratio (EDS) increased from 1.28 $\left(\mathrm{AASB}_{0}\right)$ to 1.85 in $\mathrm{AASB}_{0.3}$ binder.

It is also important to note that the presence of more pores accelerates the carbonation of SMF binders (Fig. 9). The inclusion of BFS improved the microstructural density thereby causing pore refinement. This is indicated by the disappearance of calcite in specimen $\mathrm{AASB}_{0.3}$ unlike in the specimen $\mathrm{AASB}_{0}$, as shown in the relevant $\mathrm{X}$-ray diffractogram in Fig. 8.

The FTIR spectra in Fig. 10 exhibits an asymmetric stretching of $\mathrm{CO}_{3}{ }^{2-}$ at $1400 \mathrm{~cm}^{-1}$ in $\mathrm{AASB}_{0}$ in contrast with its lower intensity in $\mathrm{AASB}_{0.3}$ corroborates less carbonation effects in the latter. There is more -OH precipitation due to the formation of portlandite or bonded
Table 4 Composition of AASB specimens with and without BFS.

\begin{tabular}{|c|c|c|}
\hline Element Wt.\% & $\begin{array}{c}\mathrm{AASB}_{0} \\
\text { (Spectrum 11) }\end{array}$ & $\begin{array}{c}\mathrm{AASB}_{0.3} \\
\text { (Spectrum 18) }\end{array}$ \\
\hline $\mathrm{O}$ & 37.1 & 34.1 \\
\hline $\mathrm{C}$ & 21.6 & 19.3 \\
\hline $\mathrm{Mn}$ & 12.58 & 7.98 \\
\hline $\mathrm{Si}$ & 8.34 & 10.34 \\
\hline $\mathrm{K}$ & 6.5 & 5.59 \\
\hline $\mathrm{Ca}$ & 2.06 & 9.79 \\
\hline $\mathrm{Na}$ & 5.42 & 5.33 \\
\hline $\mathrm{Al}$ & 0.5 & 2.04 \\
\hline $\mathrm{Ca} / \mathrm{Si}$ & 0.25 & 0.95 \\
\hline $\mathrm{Ca} / \mathrm{Mn}$ & 0.16 & 1.23 \\
\hline $\mathrm{Si} / \mathrm{Mn}$ & 0.66 & 1.30 \\
\hline $\mathrm{Ca} / \mathrm{K}$ & 0.32 & 1.75 \\
\hline $\mathrm{Si} / \mathrm{K}$ & 1.28 & 1.85 \\
\hline
\end{tabular}

water molecule as noted with a deep band of asymmetric stretching of $-\mathrm{OH}$ at wavenumber of $3375 \mathrm{~cm}^{-1}$ in the $\mathrm{AASB}_{0}$ system. This points to the weakness of its microstructure unlike the shallow band noticed in $\mathrm{AASB}_{0.3}$ system. Further, a pronounced band at a wavenumber of $1644 \mathrm{~cm}^{-1}$ depicting $\mathrm{H}-\mathrm{O}-\mathrm{H}$ symmetrical bending in $\mathrm{AASB}_{0}$ also supports the weaker microstructure (Fig. 9) of the specimen $\mathrm{AASB}_{0}$ in comparison with a more stable $\mathrm{AASB}_{0.3}$ specimen. The possible attachment of $\mathrm{Ca}$ to $\mathrm{Si}-\mathrm{O}$ - to build $\mathrm{Ca}$-aluminosilicate molecules (Ca-Si-O$\mathrm{T}$ ) in specimen $\mathrm{AASB}_{0.3}$ shows the asymmetric stretching of Si-O-T compared to specimen $\operatorname{AASB}_{0}\left(972 \mathrm{~cm}^{-1}\right)$ with low calcium content. This suggests a low silicate re-organization in $\mathrm{AASB}_{0}$ with the consequence of the poor strength due to the fragmented skeletal framework.
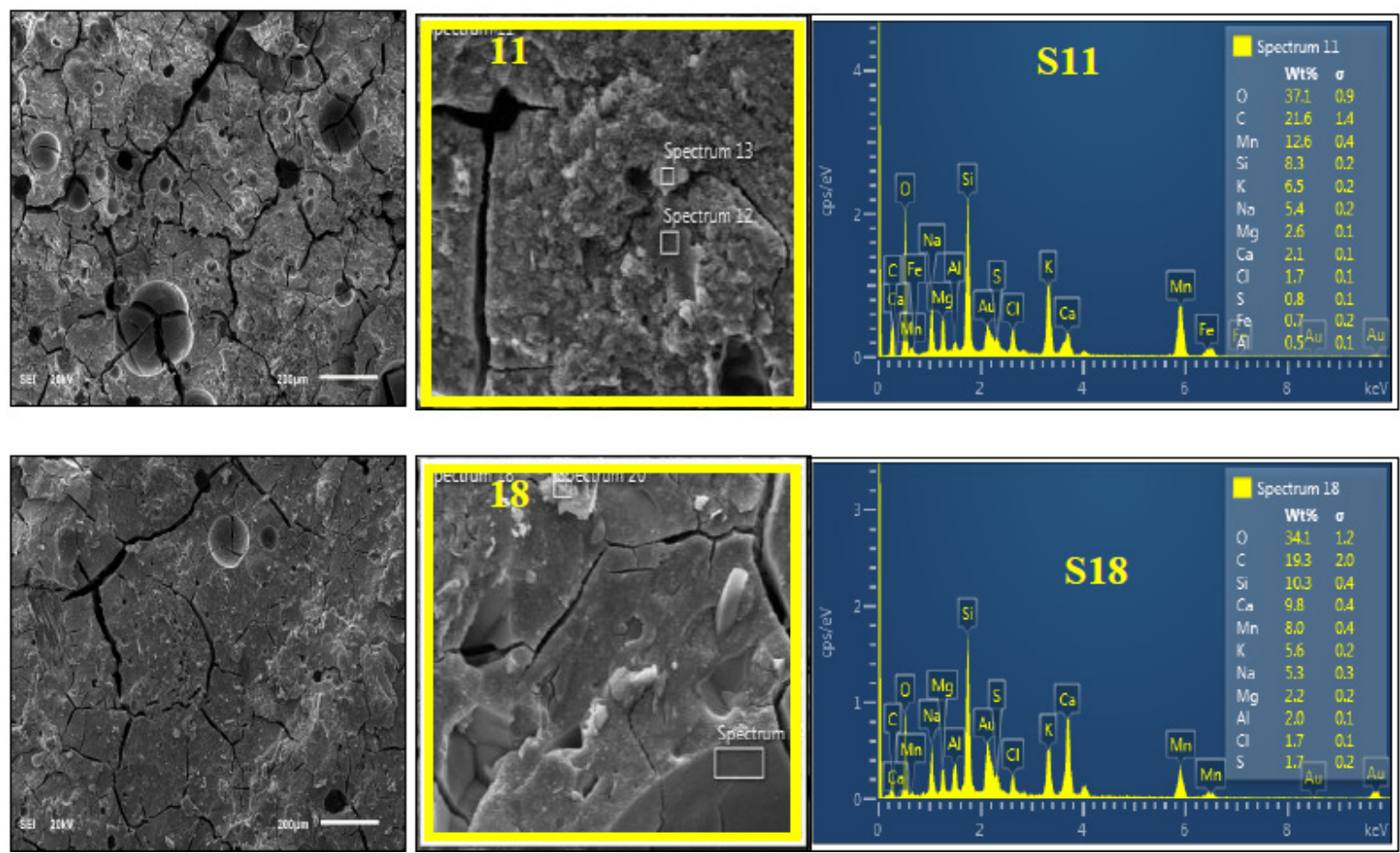

Fig. 9 SEM and EDS of specimens $\mathrm{AASB}_{0}$ (top) and $\mathrm{AASB}_{0.3}$ (bottom). 


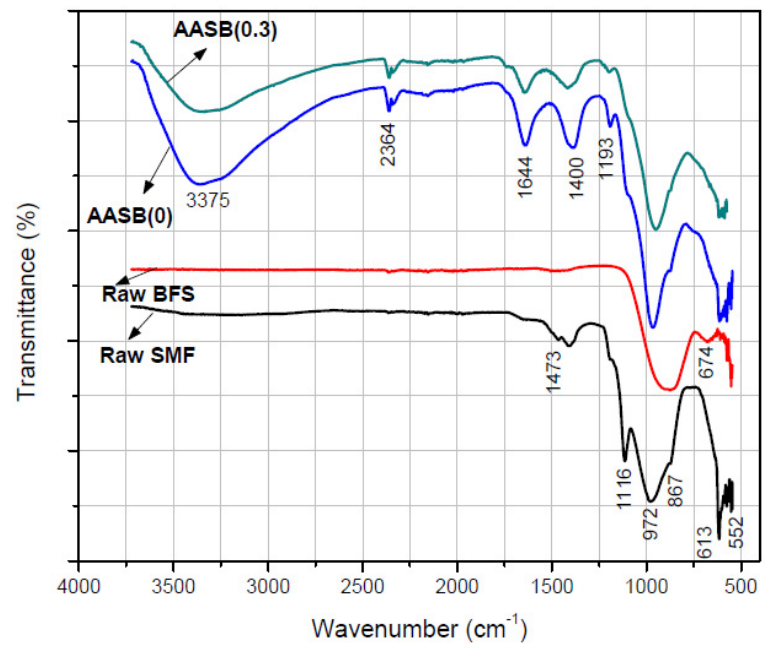

Fig. 10 FT-IR spectra for raw PMs and AASB specimens.

\section{Conclusions}

In this study, low temperature cured alkaline activated binary binders (AASB) were developed with the synergy of silico-manganese fume (SMF) and blast furnace slag (BFS). The following conclusions can be drawn based on the experimental data obtained in the reported study.

(1) The spherical nature of SMF improved the workability of the mixture while the workability of the AASB system mainly increased with increasing $\mathrm{MnO} / \mathrm{CaO}$ ratio. The inclusion of BFS decreased this ratio and hence negatively affected the consistency of the mixture. Extended mixing time also lowered this ratio due to the dissolution of more $\mathrm{CaO}$ and the consequent decrease in the consistency.

(2) The setting time of AASB system depends on the $\mathrm{CaO} / \mathrm{SiO}_{2}$ ratio. The increase in BFS content tend to reduce setting time due to accelerated product formation. The effect of BFS in the product formation is more pronounced at the later age.

(3) The compressive strength of the developed binders and microstructural density was influenced by the $\mathrm{Ca} / \mathrm{Si}, \mathrm{Ca} / \mathrm{Mn}, \mathrm{Si} / \mathrm{Mn}$ ratios.

(4) The strength gain in the developed binders is attributed to the dual presence of calcium silicate hydrate (C-S-H) and the formation of stratlingite/gehlenite hydrate (C-A-S-H), and nchwaningite/glaucochroite (C-Mn-S-H) phases.

(5) The compressive strength increased up to $30 \%$ BFS (AASB). A maximum compressive strength of about $45 \mathrm{MPa}$ was noted after 28 days when the specimen $\left(\mathrm{AASB}_{0.3}\right)$ is cured under the condition of ambient temperature $\left(25^{\circ} \mathrm{C}\right)$.

(6) The inclusion of BFS in $\mathrm{AASB}_{0.3}$ system enhanced the reactivity of potassium oxide leading to the formation of potassium feldspar (K-A-S-H) and an increase in $\mathrm{K} / \mathrm{Ca}$ ratio.

(7) Excessive carbonation effect and weak hydroxyl compound of alkaline activated silico-manganese fume could be reduced by the synergistic-interaction of BFS and SMF due to increase in the microstructural density and the reduction in microcracks by pore filling effects.

\section{Acknowledgment}

School of Civil Engineering at Universiti Sains Malaysia and King Fahd University of Petroleum and Minerals are gratefully acknowledged for providing needed support for the reported research.

\section{References}

Abdulkareem, O. M., Fraj, A. B., Bouasker, M. and Khelidj, A., (2018). "Mixture design and early age investigations of moresustainable UHPC." Construction and Building Materials, 163, 235-246.

Bernal, S. A., Rodríguez, E. D., Gutiérrez, R. M. D., Gordillo, M. and Provis, J. L., (2011). "Mechanical and thermal characterisation of geopolymers based on silicate-activated metakaolin/slag blends." Journal of Material Science, 46(16), 5477-5486.

Bonk, F., Schneider, J., Cincotto, M. A. and Panepucci, H., (2003). "Characterization by multinuclear highresolution NMR of hydration products in activated blast-furnace slag pastes." Journal of the American Ceramic Society, 86(10), 1712-1719.

Fernández-Jiménez, A. and Puertas, F., (2001). "Setting of alkali-activated alag cement. influence of activator nature." Advances in Cement Research, 13(3), 115-121.

Fernández-Jiménez, A., Puertas, F., Sobrados, I. and Sanz, J., (2003). "Structure of calcium silicate hydrates formed in alkaline-activated alag: Influence of the type of alkaline activator." Journal of the American Ceramic Society, 86(8), 1389-1394.

Frias, M, Rojas, M. I. S. D., Menendez, I., Lomas, M. G. D. and Rodriguez, C., (2005). "Properties of SiMn alag as apozzolanic aaterial in Portland aement manufacture." Materiales de Construcción 55(280), 53-62.

Frias, M. and Rodríguez, C., (2008). "Effect of incorporating ferroalloy industry wastes as complementary cementing materials on the properties of blended cement matrices." Cement and Concrete Composites, 30(3), 212-219.

Haha, M. B., Saout, G. L., Winnefeld, F. and Lothenbach, B., (2011). "Influence of activator type on hydration kinetics, Hydrate assemblage and microstructural development of alkali activated blast-furnace slags." Cement and Concrete Research, 41(3), 301-310.

Heah, C. Y., Kamarudin, H., Al Bakri, A. M. M., Bnhussain, M., Luqman, M., Nizar, I. K., Ruzaidi, C. M. and Liew, Y. M., (2013). "Kaolin-based geopolymers with various $\mathrm{NaOH}$ concentrations." International Journal of Minerals, Metallurgy and Materials, 20(3), 313-322.

Ibrahim, M., Johari, M. A. M., Rahman, M. K. and Maslehuddin, M., (2017). "Effect of alkaline activators and binder content on the properties of natural pozzolanbased akali activated concrete." Construction and Building Materials, 147, 648-660. 
Ibrahim, M., Johari, M. A. M., Maslehuddin, M., Rahman, M. K., Salami, B. A. and Mohamed, H. D., (2019). "Influence of composition and concentration of alkaline activator on the properties of natural-pozzolan based green concrete." Const. and Build. Mat. 201, 186-195.

Kumar, S., García-Triñanes, P., Teixeira-Pinto, A. and Bao, M., (2013). "Development of alkali activated cement from mechanically activated silico-manganese ( $\mathrm{SiMn}$ ) slag." Cement and Concrete Composites, 40, 7-13.

Liu, S., Li, Q. and Han, W., (2018). "Effect of various alkalis on hydration properties of alkali-activated slag cements." Journal of Thermal Analysis and Calorimetry, 131(3), 3093-3104.

Mohseni, E. (2018). “Assessment of $\mathrm{Na}_{2} \mathrm{SiO}_{3}$ to $\mathrm{NaOH}$ ratio impact on the performance of polypropylene fiberreinforced geopolymer composites." Construction and Building Materials, 186, 904-911.

Nagaraj V. K. and Babu, D. L. V., (2018). “Assessing the performance of molarity and alkaline activator ratio on engineering properties of self-compacting alkaline activated concrete at ambient temperature." Journal of Building Engineering, 20, 137-155.

Najamuddin, S. K., Johari, M. A. M., Maslehuddin, M. and Yusuf, M. O., (2019). "Synthesis of low temperature cured alkaline activated silicomanganese fume mortar." Construction and Building Materials, 200, 387-397.

Nath, S. K. and Kumar, S., (2016). "Evaluation of the suitability of ground granulated silico-manganese slag in Portland slag cement." Construction and Building Materials, 125, 127-134.

Péra, J., Ambroise, J. and Chabannet, M., (1999). "Properties of blast-furnace slags containing high amounts of manganese." Cement and Concrete Research, 29(2), 171-177.

Phoo-ngernkham, T., Hanjitsuwan, S., Suksiripattanapong, C., Thumrongvut, J., Suebsuk, J. and Sookasem, S., (2016). "Flexural strength of notched concrete beam filled with alkali-activated binders under different types of alkali solutions." Construction and Building Materials, 127, 673-678.

Phoo-Ngernkham, T., Maegawa, A., Mishima, N., Hatanaka, S. and Chindaprasirt, P., (2015). "Effects of sodium hydroxide and sodium silicate solutions on compressive and shear bond strengths of FA-GBFS geopolymer." Construction and Building Materials,
91, 1-8.

Provis, J. L., (2014). "Geopolymers and other alkali activated materials: Why, How, and What?" Materials and Structures, 47(1-2), 11-25.

Puertas, F., Martínez-Ramírez, S., Alonso, S. and Vazquez, T., (2000). "Alkali-activated fly ash/slag sements: Strength behaviour and hydration products." Cement and Concrete Research, 30(10), 1625-1632.

Puertas, F., Varga, C. and Alonso, M. M., (2014). "Rheology of alkali-activated slag pastes. Effect of the nature and concentration of the activating solution." Cement and Concrete Composites, 53, 279-288.

Rashad, A. M., (2013). "Properties of alkali-activated fly ash concrete blended with slag." Iran. J. Mater. Sci. Eng, 10(1), 57-64.

Salami, B. A., Johari, M. A. M., Ahmad, Z. A. and Maslehuddin, M., (2017). "POFA-engineered alkaliactivated cementitious composite performance in acid fnvironment." Journal of Advanced Concrete Technology, 15(11), 684-699.

Vu, T. H. and Gowripalan, N., (2018). "Mechanisms of heavy metal immobilisation using geopolymerisation techniques-a review." Journal of Advanced Concrete Technology, 16(3), 124-135.

Yusuf, M. O., Johari, M. A. M., Ahmad, Z. A. and Maslehuddin, M., (2014a). "Influence of curing methods and concentration of $\mathrm{NaOH}$ on strength of the synthesized alkaline activated ground slag-ultrafine palm oil fuel ash mortar/concrete." Construction and Building Materials, 66, 541-548.

Yusuf, M. O., Johari, M. A. M., Ahmad, Z. A. and Maslehuddin, M., (2014b). "Strength and microstructure of alkali-activated binary blended binder containing palm oil fuel ash and ground blast-furnace slag." Construction and Building Materials, 52, 504-510.

Zhang, Y. J., Zhao, Y. L. and Li, H. H., (2008). "Structure characterization of hydration products generated by alkaline activation of granulated blast furnace slag." Journal of Materials Science, 43(22), 7141-7147.

Zhong, Y., Qiu, X., Gao, J. and Guo, Z., (2017). "Recovery of soluble potassium from electric arc furnace dust of manganese alloy production: Characterization and water leaching kinetics." ISIJ International, 58(1), 194-200. 